\title{
Differential Cytomorphometric Analysis of Keratinized Fiber Cells in Human Oral Carcinoma
}

\author{
*Dr Abhimanyu Mohanta, Ph.D. ${ }^{1}$; Dr Prafulla K. Mohanty, Ph.D. ${ }^{2}$; \\ Dr Gadadhar Parida, M.D. ${ }^{3}$ \\ ${ }^{1}$ Lecturer in Zoology, Biju Pattnaik College, Singda, Mayurbhanj, Odisha, India-757039. \\ ${ }^{2}$ Professor and Head, P.G. Department of Zoology, Utkal University, Vani Vihar, Bhubaneshwar, \\ Odisha, India-751 004. \\ ${ }^{3}$ Former Director, Professor and Head, Department of Oncopathology, Acharya Harihar Regional \\ Cancer Centre (AHRCC), Cuttack, Odisha, India-753 007. \\ *Corresponding Author, Email: amohanta01@gmail.com
}

\begin{abstract}
:
Background: Use of exfoliative cytology and cyto-analysis is a useful early diagnostic method for epithelial atypia and for human oral neoplasm. Rare occurrences of cytological atypia appear to be very thin, elongated, fibre like structures in oral epithelia is named as keratinized fiber cells (KFCs). In the present study, the aim is to quantify the KFCs and to analyze it morphometrically with a cytodiagnostic approach.

Materials and Methods: In a case-control study, exfoliated scraped cytosmears were collected from the affected sites of the clinically diagnosed 136 oral cancer patients over the pre-cleaned microslides and immediately fixed in acetoalcohol. Cytosmears were stained with routine Papanicolaou's stain and counterstained with the Giemsa's solution. Out of one thousand screened cells, the KFCs were scored from each stained sample following standard criteria. Cytomorphometry was done by using computer-assisted Cat Cam 1.30 (1.3 Mega Pixel) microscope camera of Catalyst Biotech ${ }^{\circledR}$ (Maharashtra, India). Findings were statistically analyzed, interpreted and correlated with the oral sites, sex and nature of addiction.

Results: Keratinized fiber cells (KFCs) exhibit both cytological and nuclear pleomorphism. Usually, two types of KFCs-named as Large Keratinized fiber cells (LKFCs) and small Keratinized fiber cells (SKFCs) were observed in $53.76 \%$ of total collected samples from the premalignant and malignant cases. Almost all KFCs are moderately differentiated with an elongated fiber contour in each and are the pleomorphic form of normal oral squamous cells. Keratin expression in the cytoplasm in KFCs indicates epidermoid origin. The terminal ends are either pin-pointed or narrowly blunt. The nucleus is also found to be elongated inside the cytoplasm of KFCs. In rare cases, the nucleiof the KFCs may be either polarized or ink-dot shaped. Cytological as well as nuclear pleomorphism, pattern of keratiniztion, hyperchromasia and increased nuclear-cytoplasmic (N/C) ratios in KFCs are of cytopathological importance and are the signs and clear indication of malignancy.

Conclusion: Genesis of KFCs in the epithelia of oral neoplasm is a sign of neo-fibrosis. Pattern of keratiniztion, hyperchromasia, nuclear pleomorphism and increased nuclear-cytoplasmic ratios (N/C) in KFCs are of cytopathological importance and thus appearance of KFCs in oral epithelia has a practical utility in early detection and diagnosis of the oral cancer patients.
\end{abstract}

Key words: Cytodiagnosis, cytosmear, exfoliative cytology, keratinized fiber cells, oral neo-fibrosis, nuclearcytoplasmic (N/C) ratios, oral fiber cell carcinoma.

\section{Introduction}

Oral cancer is considered as a serious public health problem that causes great morbidity and mortality in the population, worldwide. Early detection of oral cancer is a challenging job for dentists and pathologists. Although surgical biopsy is the Gold Standard for diagnosing oral lesions, it is impractical to routinely subject large numbers of patients to biopsy [1]. Alternatively, diagnostic cytology introduced by George Nikolaou Papanicolaou as a tool to detect cancer and pre-cancer in 1928 is now widely accepted for mass screening in asymptomatic population. Silverman et al. have suggested that cytological technique, being simple and less injury-producing procedure, has the advantage of doing away with many undesirable features of a biopsy and that offers a simple yet reliable method of great predictability in cancer detection programme [2]. Stromby has opined that cytology is reliable diagnostic tool in diagnosis of presence or absence of malignancy in a lesion with high accuracy rate. Clinical cytology, in the hands of well trained personnel now possesses a sensitivity of 92 to $100 \%$ while its specificity has risen to somewhere between 97 to $100 \%$ [3]. Use of exfoliative cytology and cytoanalysis is a useful early diagnostic method for epithelial atypia and for oral lesion [4]. The oral cytologic technique is easy to do and can provide the help of surgeon/physician, where he/she might hesitate to 
perform an invasive procedure, like a biopsy, or desire more information regarding a lesion before referring the patient [5].

Mc Kinley has categorically stated that the cytopathologists very often encounter problems in detection and diagnoses of the oral cancer patients as most of the oral squamous cells appear to be either well differentiated or moderately differentiated and mimic to be benign and non-neoplastic. Contrary to that, many benign and non-neoplastic lesions appear to be malignant neoplasms [6]. Parida has also reported that a practical difficulty arises with well-differentiated squamous cell carcinoma in cytologic examinations as in many of these cases nuclear characteristic of malignancy, such as hyperchromatism and an increased nuclear/cytoplasmic ratio, are not marked [7]. In the present study, an attempt for differential cytodiagnosis was undertaken to assess the origin of pleomorphic keratinized fiber cells (KFCs) in oral premalignant and malignant lesions and its practical utility in early detection during oral carcinogenesis through cytomorphometric analysis.

\subsection{Collection of samples}

\section{Materials and Methods}

Exfoliated scrape smears were collected from the clinically diagnosed 136 patients suffering from precancerous lesions and oral squamous cell carcinoma (OSCC) at the Out Patient Department (OPD) of Acharya Harihar Regional Cancer Center (AHRCC), Cuttack, Odisha, during May 2007-May 2009. Smearing was done on the pre-cleaned-coded microslides and the slides were fixed in aceto-alcohol (1:3) fixative, immediately. On the basis of International Classification of Diseases (ICD-10) by World Health Organization (WHO), two slides were smeared and prepared from each affected sites of the patient. Prior to the collection of samples, case-history of the patients related to their age, sex, food, habits, oral hygiene and occupation were asked and recorded for detail analysis. Out of 136 patients, $126(92.65 \%)$ were addicted to different forms of tobacco and alcohol for more than 15 years and the rest 10 (7.35\%) were absolutely non-addicted. A parallel set of 136 samples were also collected from the non-addicted and non-cancerous individuals from different regions of Odisha which is called as control group. This study was approved by Subject Research Committee (SRC) of Utkal University, Bhubaneshwar, Odisha, India and necessary permission was also obtained from the Director, AHRCC, Cuttack, Odisha, India.

\section{II.2. Staining protocol and scoring of KFCs}

Wet fixed cytosmears were stained by adopting Papanicolaou's staining protocol and counterstained with the Giemsa's solution. One thousand cells were screened and the KFCs were scored from each stained sample following standard criteria.

\section{II.3 Statistical analyses}

The mean length and breadth of the KFCs was taken into account as length and breadth of the respective KFC, as each cell was measured at three different regions (middle and on its either sides) - in length and breadth-wise by using computer-assisted Cat Cam 1.30 (1.3 Mega Pixel) microscope camera of Catalyst $\boldsymbol{B i o t e c h}^{\circledast}$ (Maharashtra, India). The measured values were tabulated. The nuclear-cytoplasmic ratio (N/C) was calculated after taking the area of the cytoplasm (C) and nucleus (N) of the respective cell. The findings were statistically analyzed and interpreted with respect to oral sites, sexes and nature of addiction.

\section{Results}

During the course of investigation, two types of fiber cells were observed, such as large keratinized fiber cells (LKFCs) and small keratinized fiber cells (SKFCs). Out of 136 patients, in 44 (53.65\%) males and in $29(53.7 \%)$ females the pleomorphic fiber cells were observed (Table 1). Floor of the mouth followed by buccal mucosa and lip were observed to be KFCs-prone site during this study. A differential analysis on account of cytomorphology and morphometry of these two cells are described as follows.

\section{Cytomorphology of KFCs}

The LKFCs are long, slender and fiber-like structures (Fig.1). These cells are found not only in unitary scattered form but also in bundles. It was observed that, a number of LKFCs were arranged in parallel to each other and form bundles. In these bundles, many LKFCs were joined one end to another to form a large wall like structure (Fig.2). These cells were mostly observed in the chewers-smokersalcoholics of different age and sexes. Multi-factor carcinogenic agents, probably, have some synergistic effect on the normal oral squamous cells to stretch and transform the normal oral squamous cells into large keratinized fiber cells. Site and age group specific enumeration of LKFCs indicate that, more number of LKFCs were recorded from the from the floor of the mouth in the age group of 30-49 years in male and both in 50-69 and 70-89 years of female. The highest relative frequency was estimated to be $33.2 \%$ from 
the buccal mucosa in male and $42.8 \%$ from the floor of the mouth in female respectively. A total of 256 LKFCs from 44 males and 229 cells from 29 females were scored.

The keratinized fiber cells, having nearly one-third of the length of the LKFCs, are said to be SKFCs. Morphologically, these cells are small fiber like elongated cells having keratinized cytoplasm. Hyperkeratosis in SKFCs is an important feature (Fig.3). Nuclei of the cells are elongated along with the cytoplasm and these appear to be deeply stained. In rare cases, the nuclei are observed to be either polarized or ink-dot like in appearance (Fig.4). These cells are not only scattered along with the other atypias in the entire smear (Fig.5) but also observed to form bundles (Fig.6). With respect to age groups and oral sites, more number of SKFCs war scored from the floor of the mouth than the other sites in the age group of 30-49 years in male and 70-89 years in female in this study. However, the highest relative percentage of SKFCs were estimated to be $32.2 \%$ in male and $40.2 \%$ in female from buccal mucosa followed by $25.2 \%$ in male and $23.3 \%$ in female scored from the floor of the mouth(Fig.7). Interestingly, not a single SKFC was observed in palatal sample from one male in the age group of 70-89 years, where only LKFCs were found there. Thus, a total of 143 SKFCs from 44 males and 194 SKFCs from 28 females were scored from all sites, respectively.

Table 1 Oral site, age group and sex-wise enumeration of atypical keratinized fiber cells (KFCs)

\begin{tabular}{|c|c|c|c|c|c|c|c|c|c|c|c|c|c|c|}
\hline \multirow{2}{*}{ No } & \multirow{2}{*}{$\begin{array}{c}\text { Oral } \\
\text { Sites } \\
(\mathrm{ICD}-10)\end{array}$} & \multirow{2}{*}{$\begin{array}{l}\text { Age } \\
\text { groups } \\
\text { in } \\
\text { years }\end{array}$} & \multicolumn{2}{|c|}{$\begin{array}{l}\text { No. of samples } \\
\text { Screened }\end{array}$} & \multicolumn{2}{|c|}{$\begin{array}{l}\text { No. of samples } \\
\text { with KFCs }\end{array}$} & \multicolumn{2}{|c|}{$\begin{array}{l}\text { No. of LKFCs } \\
\text { Scored }\end{array}$} & \multicolumn{2}{|c|}{$\begin{array}{c}\text { Total no. of } \\
\text { LKFCs Scored* }\end{array}$} & \multicolumn{2}{|c|}{$\begin{array}{l}\text { No. of SKFCs } \\
\text { Scored }\end{array}$} & \multicolumn{2}{|c|}{$\begin{array}{c}\text { Total SKFCs } \\
\text { Scored }\end{array}$} \\
\hline & & & Male & Female & Male & Female & Male & Female & Male & Female & Male & Female & Male & Female \\
\hline \multirow{3}{*}{1} & \multirow{3}{*}{ Lip } & $30-49$ & 2 & Nil & 1 & Nil & 8 & Nil & \multirow{3}{*}{$\begin{array}{c}25 \\
(9.8)\end{array}$} & \multirow{3}{*}{$\begin{array}{c}32 \\
(14.0)\end{array}$} & 7 & Nil & \multirow{3}{*}{$\begin{array}{c}26 \\
(18.1)\end{array}$} & \multirow{3}{*}{$\begin{array}{c}17 \\
(8.7)\end{array}$} \\
\hline & & $50-69$ & 2 & 4 & 2 & 1 & 12 & 20 & & & 10 & 8 & & \\
\hline & & 70-89 & 1 & 2 & 1 & 1 & 5 & 12 & & & 9 & 9 & & \\
\hline \multirow{3}{*}{2} & \multirow{3}{*}{ Tongue } & $30-49$ & 5 & 2 & 2 & 1 & 12 & 6 & \multirow{3}{*}{$\begin{array}{c}27 \\
(10.5)\end{array}$} & \multirow{3}{*}{$\begin{array}{c}18 \\
(7.9)\end{array}$} & 6 & 2 & \multirow{3}{*}{$\begin{array}{c}14 \\
(9.8)\end{array}$} & \multirow{3}{*}{$\begin{array}{c}18 \\
(9.3)\end{array}$} \\
\hline & & $50-69$ & 5 & 4 & 4 & 2 & 13 & 8 & & & 5 & 10 & & \\
\hline & & $70-89$ & 1 & 1 & 1 & 1 & 2 & 4 & & & 3 & 6 & & \\
\hline \multirow{3}{*}{3} & \multirow{3}{*}{$\begin{array}{l}\text { Alveolus } \\
\text { and gingiva }\end{array}$} & $30-49$ & 4 & 3 & 2 & 2 & 10 & 16 & \multirow{3}{*}{$\begin{array}{c}41 \\
(16.0)\end{array}$} & \multirow{3}{*}{$\begin{array}{c}35 \\
(15.3)\end{array}$} & 2 & 15 & \multirow{3}{*}{$\begin{array}{c}18 \\
(12.8)\end{array}$} & \multirow{3}{*}{$\begin{array}{c}31 \\
(15.9)\end{array}$} \\
\hline & & $50-69$ & 8 & 3 & 6 & 3 & 23 & 19 & & & 12 & 16 & & \\
\hline & & $70-89$ & 4 & Nil & 2 & Nil & 8 & Nil & & & 4 & Nil & & \\
\hline \multirow{3}{*}{4} & \multirow{3}{*}{$\begin{array}{c}\text { Floor of the } \\
\text { mouth }\end{array}$} & $30-49$ & 4 & 1 & 1 & 1 & 32 & 14 & \multirow{3}{*}{$\begin{array}{c}66 \\
(25.8)\end{array}$} & \multirow{3}{*}{$\begin{array}{c}98 \\
(42.8)\end{array}$} & 13 & 7 & & \\
\hline & & $50-69$ & 2 & 4 & 2 & 3 & 22 & 63 & & & 15 & 22 & $\begin{array}{c}37 \\
(25.8)\end{array}$ & $\begin{array}{c}45 \\
(23.3)\end{array}$ \\
\hline & & $70-89$ & 1 & 1 & 1 & 1 & 12 & 21 & & & 09 & 16 & & \\
\hline & & $30-49$ & 4 & 1 & 1 & 1 & 7 & 5 & & & Nil & 1 & & \\
\hline 5 & Palate & $50-69$ & 1 & 2 & 1 & 1 & 2 & 10 & $\begin{array}{c}12 \\
(4.7)\end{array}$ & $\begin{array}{c}15 \\
(6.5)\end{array}$ & 2 & 4 & $\begin{array}{c}2 \\
(1.3)\end{array}$ & $\begin{array}{c}5 \\
(2.6)\end{array}$ \\
\hline & & $70-89$ & 1 & Nil & 1 & Nil & 3 & Nil & & & Nil & Nil & & \\
\hline 6 & & $30-49$ & 14 & 4 & 6 & 3 & 24 & 8 & 85 & 31 & 8 & 6 & 46 & 78 \\
\hline & $\begin{array}{l}\text { Buccal } \\
\text { mucosa }\end{array}$ & $50-69$ & 16 & 9 & 7 & 6 & 36 & 17 & $(33.2)$ & (13.5) & 32 & 68 & $(32.2)$ & $(40.2)$ \\
\hline & & $70-89$ & 7 & 3 & 3 & 2 & 25 & 6 & & & 6 & 4 & & \\
\hline & All sites & $30-89$ & 82 & 54 & 44 & 29 & 256 & 229 & 256 & 229 & 143 & 194 & 143 & 194 \\
\hline
\end{tabular}

* Figures in parentheses indicate the relative percentage.

\section{Cytometric analysis of KFCs}

On account of cytomorphometrical analysis, earlier we have already reported that the mean length and breadth of the normal oral squamous cell (NOSC) in male (Table 2) were $86.50 \mu \mathrm{m}( \pm 17.234 \mu \mathrm{m})$ and $64.23 \mu \mathrm{m}( \pm 12.125 \mu \mathrm{m})$ respectively having an area of $5555.89 \mu \mathrm{m}^{2}\left(+208.362 \mu \mathrm{m}^{2}\right)$. The nucleus of the NOSC in male was measured to be $12.95 \mu \mathrm{m}( \pm 3.368 \mu \mathrm{m})$ in length and $12.43 \mu \mathrm{m}( \pm 3.235 \mu \mathrm{m})$ in breadth with an area of $160.968 \mu \mathrm{m}^{2}\left( \pm 10.895 \mu \mathrm{m}^{2}\right)$. The nuclear-cytoplasmic ratio (N/C) in males was calculated to be 1:34.5. In case of females (Table 2), the mean length, breadth and area of NOSC were recorded to be $85.895 \mu \mathrm{m}( \pm 16.374 \mu \mathrm{m}), 65.012 \mu \mathrm{m}( \pm 11.876 \mu \mathrm{m})$ and $5582.905 \mu \mathrm{m}^{2}\left( \pm 194.457 \mu \mathrm{m}^{2}\right)$ respectively. The mean 
length and breadth of the nucleus were $12.920 \mu \mathrm{m}( \pm 3.544 \mu \mathrm{m})$ and $12.530 \mu \mathrm{m}( \pm 3.452 \mu \mathrm{m})$. Thus, the mean nuclear area of the NOSC in females was found to be $161.887 \mu \mathrm{m}^{2}\left(+12.233 \mu \mathrm{m}^{2}\right)$. Hence, the nuclearcytoplasmic (N/C) ratio was found to be 1:34.4 in females [8].

Cytometrically, the mean length and breadth of LKFCs in male were measured to be $141.18 \mu \mathrm{m}$ $( \pm 22.786 \mu \mathrm{m})$ and $1.364( \pm 2.076 \mu \mathrm{m})$ respectively and thus, the area of the cell was found to be $1886.785 \mu \mathrm{m}^{2}\left( \pm 47.30 \mu \mathrm{m}^{2}\right)$. The mean length and breadth of the nucleus was measured to be $25.019 \mu \mathrm{m}$ $( \pm 1.850 \mu \mathrm{m})$ and $6.689 \mu \mathrm{m}( \pm 1.235 \mu \mathrm{m})$. The calculated mean nuclear area of the cell was $1.67 .376 \mu \mathrm{m}^{2}$ $\left( \pm 2.284 \mu \mathrm{m}^{2}\right)$. Thus, the N/C ratio in males was found to be 1:11.2 in large keratinized fiber cells. In case of female, the mean length, breadth and area of the LKFC were calculated to be $135.450 \mu \mathrm{m}$ $( \pm 28.742 \mu \mathrm{m}), 12.316 \mu \mathrm{m}( \pm 1.864 \mu \mathrm{m})$ and $1668.202 \mu \mathrm{m}^{2}\left( \pm 53.575 \mu \mathrm{m}^{2}\right)$ respectively. The mean length, breadth and area of the nucleus were measured to be $2.213 \mu \mathrm{m}( \pm 2.208 \mu \mathrm{m}), 5.411 \mu \mathrm{m}( \pm 1.215 \mu \mathrm{m})$ and $147.249 \mu \mathrm{m}^{2}\left( \pm 2.682 \mu \mathrm{m}^{2}\right)$ respectively. Thus, the N/C ratio of LKFC was 1:11.3 in females (Fig s.8-9).

Cytometrical analysis of the SKFCs revealed that the mean length, breadth and area of a cell were calculated to be $45.584 \mu \mathrm{m}( \pm 3.612 \mu \mathrm{m}), 8.806 \mu \mathrm{m}( \pm 2.125 \mu \mathrm{m})$ and $401.412 \mu \mathrm{m}^{2}\left( \pm 5.737 \mu \mathrm{m}^{2}\right)$ and the nuclear mean length, breadth and area were measured to be $15.022 \mu \mathrm{m}( \pm 2.103 \mu \mathrm{m}), 4.144 \mu \mathrm{m}( \pm 0.87 \mu \mathrm{m})$ and $62.251 \mu \mathrm{m}^{2}\left( \pm 1.829 \mu \mathrm{m}^{2}\right)$ respectively in males. Thus, the N/C ratio in SKFCs was recorded to be 1:6.4. In case of females, the length, breadth and area of the SKFC were found to be $44.135 \mu \mathrm{m}( \pm 2.075 \mu \mathrm{m})$, $8.246 \mu \mathrm{m}( \pm 2.825 \mu \mathrm{m})$ and $363.937 \mu \mathrm{m}^{2}( \pm 2.075 \mu \mathrm{m}) 8.246 \mu \mathrm{m}( \pm 2.825 \mu \mathrm{m})$ and $363.937 \mu \mathrm{m}^{2}\left( \pm 8.075 \mu \mathrm{m}^{2}\right)$ respectively. The mean length, breadth and area of the nucleus were found to be $16.890 \mu \mathrm{m}( \pm 2.132 \mu \mathrm{m})$, $3.225 \mu \mathrm{m}( \pm 1.376 \mu \mathrm{m})$ and $54.470 \mu \mathrm{m}^{2}\left( \pm 2.933 \mu \mathrm{m}^{2}\right)$. Thus, the N/C ratio of SKFCs in females was calculated to be 1: 6.6 (Figs.8-9).

Table 2 Cytometric analysis of keratinized Fiber cells (KFCs) along with normal oral squamous cells in both sexes

\begin{tabular}{|c|c|c|c|c|c|c|c|c|c|c|}
\hline \multirow[t]{2}{*}{ No } & \multirow[t]{2}{*}{$\begin{array}{l}\text { Cell } \\
\text { type }\end{array}$} & \multirow[t]{2}{*}{ Sex } & \multirow{2}{*}{$\begin{array}{l}\text { No of } \\
\text { cells } \\
\text { scored }\end{array}$} & \multicolumn{3}{|c|}{ Cytoplasm (C) } & \multicolumn{3}{|c|}{ Nucleus (N) } & \multirow[t]{2}{*}{$\begin{array}{l}\text { N/C } \\
\text { Ratio }\end{array}$} \\
\hline & & & & $\begin{array}{l}\text { Mean } \\
\text { length in } \\
\mu \mathrm{m}+\mathrm{SD}\end{array}$ & $\begin{array}{l}\text { Mean } \\
\text { breadth } \\
\text { in } \mu \mathrm{m} \pm \\
\text { SD }\end{array}$ & $\begin{array}{l}\text { Mean area } \\
\text { in } \mu \mathrm{m}^{2} \pm \\
\text { SD }\end{array}$ & $\begin{array}{l}\text { Mean } \\
\text { length in } \\
\mu \mathrm{m} \quad \pm \\
\mathrm{SD}\end{array}$ & $\begin{array}{l}\text { Mean } \\
\text { breadth } \\
\text { in } \mu \mathrm{m} \pm \\
\text { SD }\end{array}$ & $\begin{array}{l}\text { Mean area } \\
\text { in } \mu \mathrm{m}^{2} \pm \\
\mathrm{SD}\end{array}$ & \\
\hline \multirow{2}{*}{1} & \multirow{2}{*}{$\begin{array}{c}\text { Normal } \\
\text { cell }\end{array}$} & Male & 1000 & $\begin{array}{c}86.50 \\
\pm 17.234\end{array}$ & $\begin{array}{c}64.23 \\
\pm 12.125\end{array}$ & $\begin{array}{c}5555.89 \\
\pm 208.362\end{array}$ & $\begin{array}{c}12.95 \\
\pm 3.368\end{array}$ & $\begin{array}{c}12.43 \\
\pm 3.235\end{array}$ & $\begin{array}{l}160.968 \\
\pm 10.895\end{array}$ & $1: 34.5$ \\
\hline & & Female & 1000 & $\begin{array}{c}85.895 \\
\pm 16.374\end{array}$ & $\begin{array}{c}65.012 \\
\pm 11.876\end{array}$ & $\begin{array}{l}5582.905 \\
\pm 194.457\end{array}$ & $\begin{array}{l}12.920 \\
\pm 3.544\end{array}$ & $\begin{array}{l}12.530 \\
\pm 3.452\end{array}$ & $\begin{array}{r}161.887 \\
\pm 12.233\end{array}$ & $1: 34.4$ \\
\hline \multirow{2}{*}{2} & \multirow{2}{*}{ LKFC } & Male & 256 & $\begin{array}{l}141.180 \\
\pm 22.786\end{array}$ & $\begin{array}{l}13.364 \\
\pm 2.076\end{array}$ & $\begin{array}{c}1886.785 \\
\pm 47.30\end{array}$ & $\begin{array}{l}25.019 \\
\pm 1.850\end{array}$ & $\begin{array}{c}6.689 \\
\pm 1.235\end{array}$ & $\begin{array}{c}167.376 \\
\pm 2.284\end{array}$ & $1: 11.3$ \\
\hline & & Female & 229 & $\begin{array}{l}135.450 \\
\pm 28.742\end{array}$ & $\begin{array}{l}12.316 \\
\pm 1.864\end{array}$ & $\begin{array}{l}1668.202 \\
\pm 53.575\end{array}$ & $\begin{array}{l}27.213 \\
\pm 2.208\end{array}$ & $\begin{array}{c}5.411 \\
\pm 1.215\end{array}$ & $\begin{array}{c}147.249 \\
\pm 2.682\end{array}$ & $1: 11.3$ \\
\hline \multirow{2}{*}{3} & \multirow{2}{*}{ SKFC } & Male & 143 & $\begin{array}{l}45.584 \\
\pm 3.612\end{array}$ & $\begin{array}{c}8.806 \\
\pm 2.125\end{array}$ & $\begin{array}{c}401.412 \\
\pm 5.737\end{array}$ & $\begin{array}{l}15.022 \\
\pm 2.103\end{array}$ & $\begin{array}{l}4.144 \\
\pm 0.87\end{array}$ & $\begin{array}{l}62.251 \\
\pm 1.289\end{array}$ & $1: 6.4$ \\
\hline & & Female & 194 & $\begin{array}{l}44.135 \\
\pm 3.075\end{array}$ & $\begin{array}{c}8.246 \\
\pm 2.825\end{array}$ & $\begin{array}{c}363.937 \\
\pm 8.686\end{array}$ & $\begin{array}{l}16.890 \\
\pm 2.132\end{array}$ & $\begin{array}{c}3.225 \\
\pm 1.376\end{array}$ & $\begin{array}{l}54.470 \\
\pm 2.933\end{array}$ & $1: 6.6$ \\
\hline
\end{tabular}

Source: Primary data. SD-Standard deviation. 


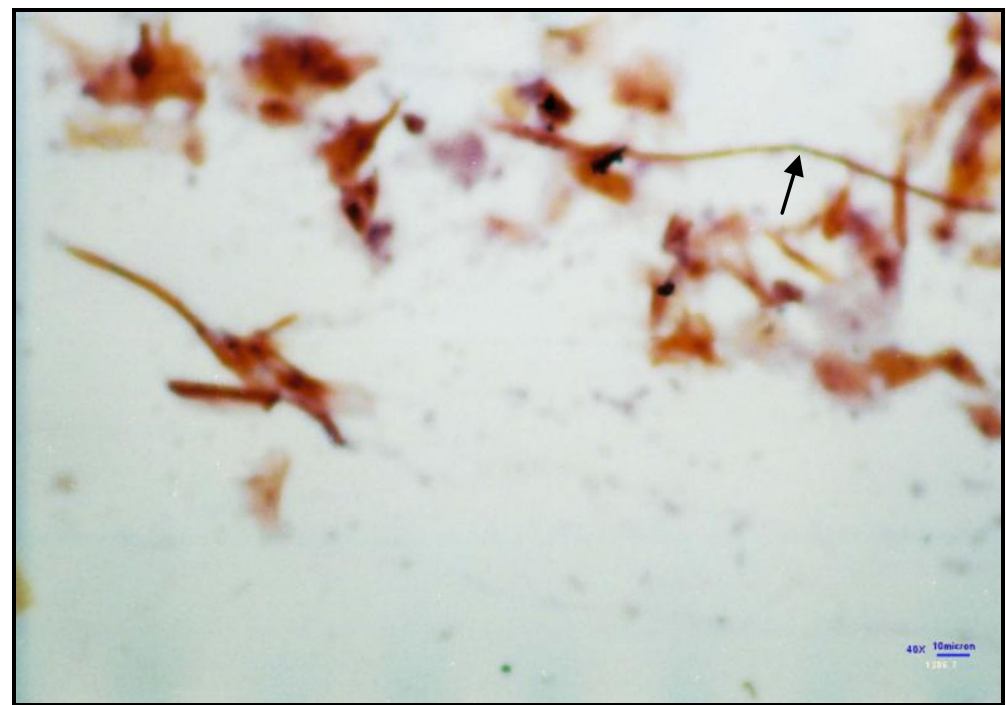

Figure 1 A large keratinized fiber cell (Papanicolaou's stain, x400).

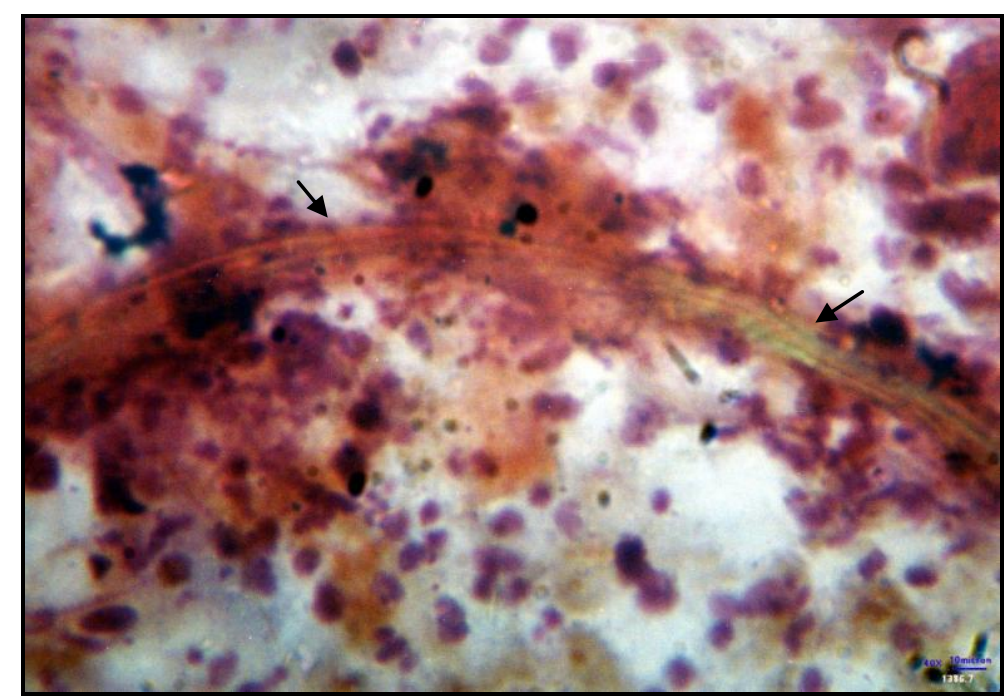

Figure 2 A bundles of LKFCs forming wall-like structure (Papanicolaou's stain, $\mathrm{x} 400$ ).

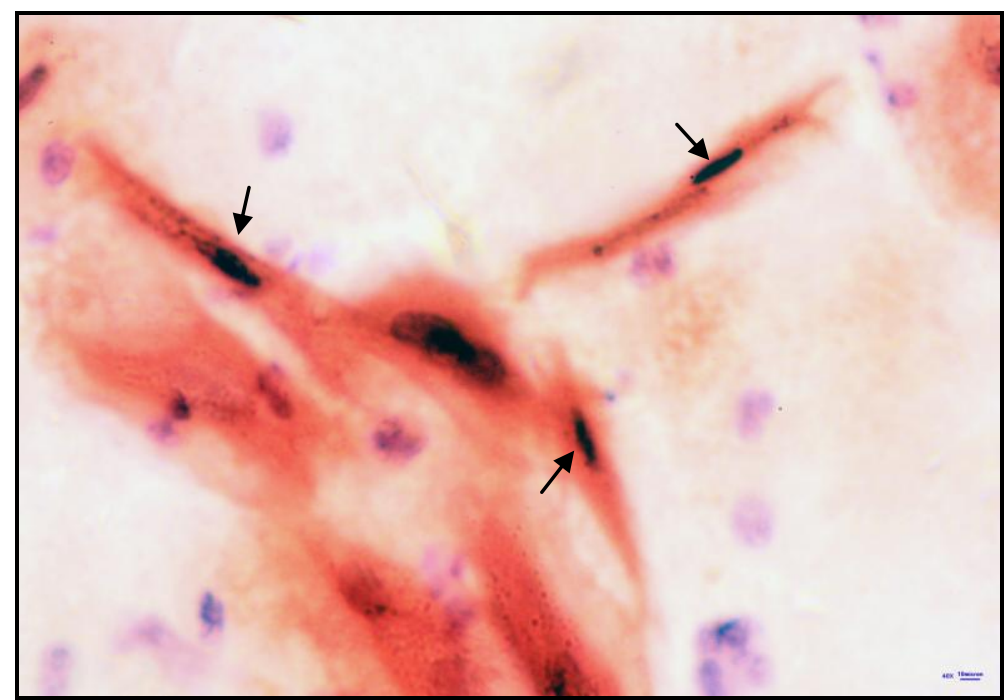

Figure 3 Unitary three small keratnized fiber cells (Papanicolaou's stain, $\mathrm{x} 400$ ). 


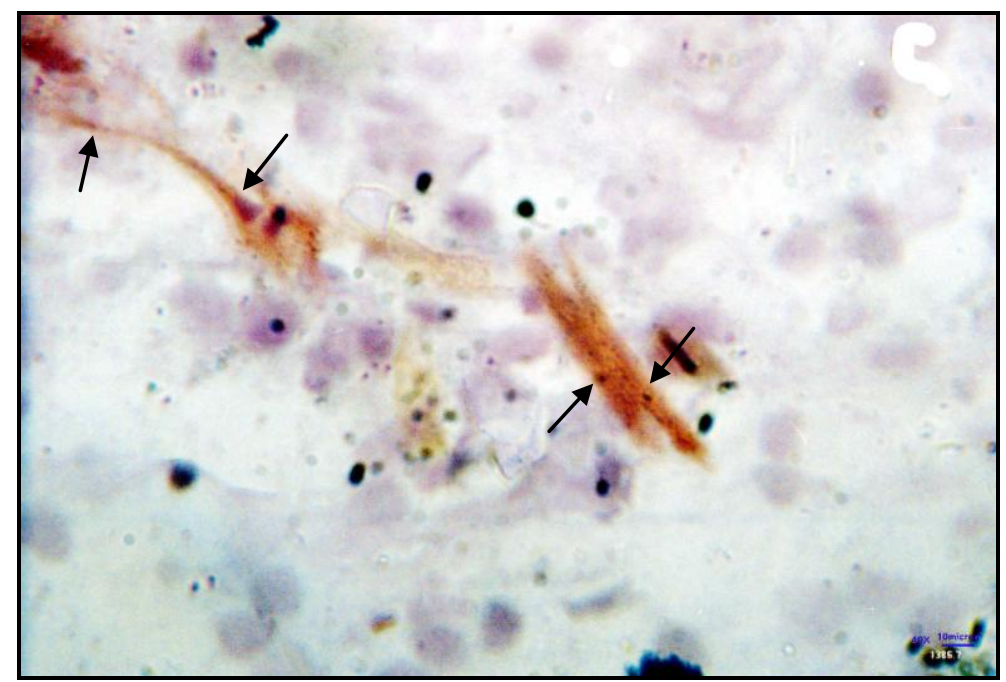

Figure 4 Polarized and ink-dot nucleus in small keratnized fiber cells (Papanicolaou's stain, x400).

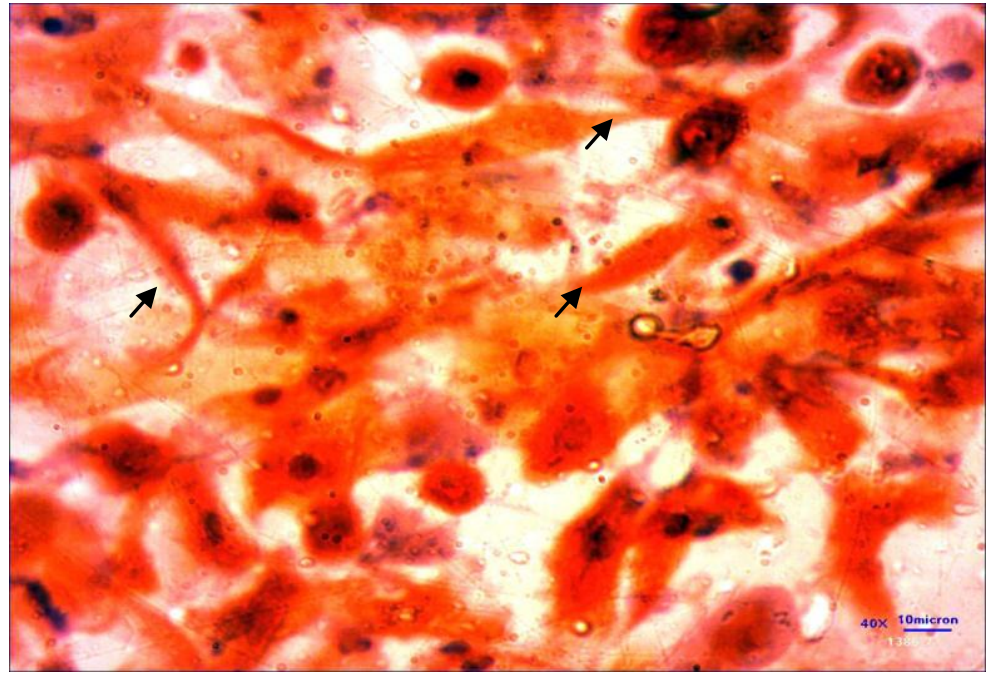

Figure 5 A number of hyperkeratinized SKFCs along with other cytological atypia (Papanicolaou's stain, x400).

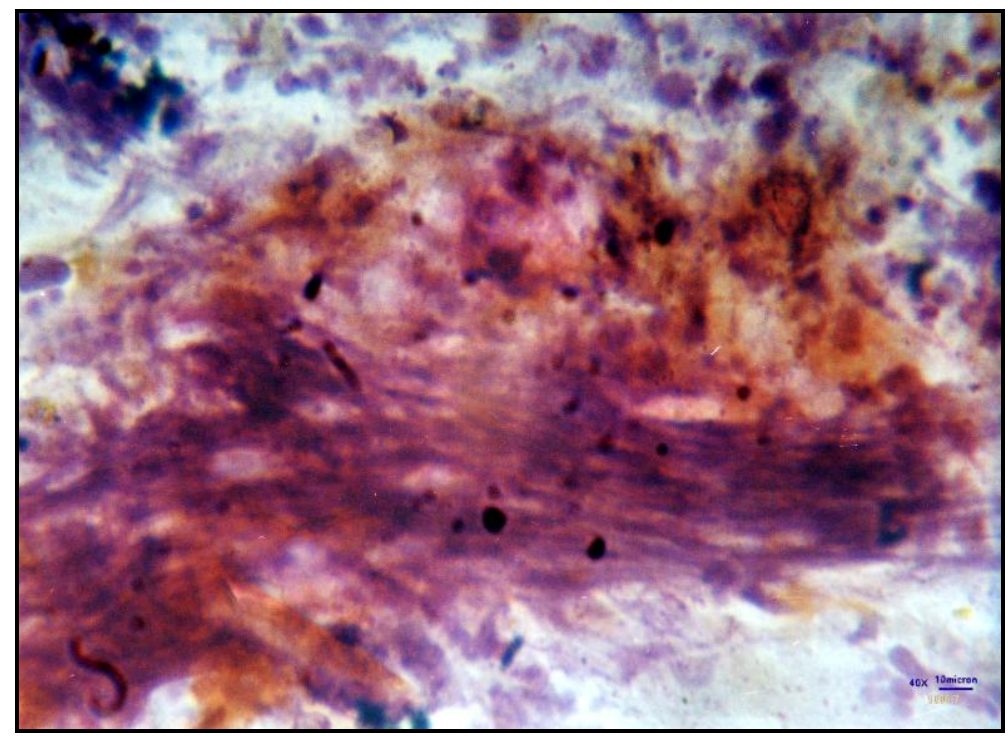

Figure 6 Bundles of SKFCs and LKFCs in oral fiber cell carcinoma (Papanicolaou's stain, $\mathrm{x} 400$ ). 


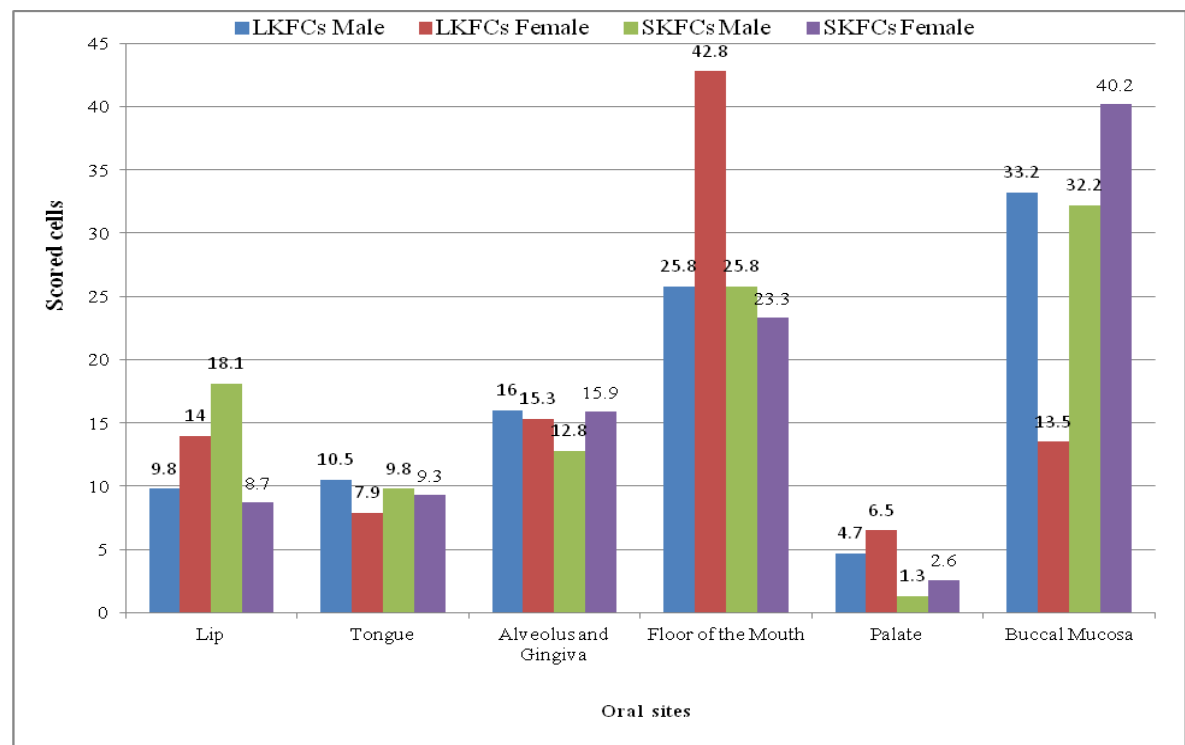

Figure 7 Oral sites and sex-wise relative percentage of KFCs.

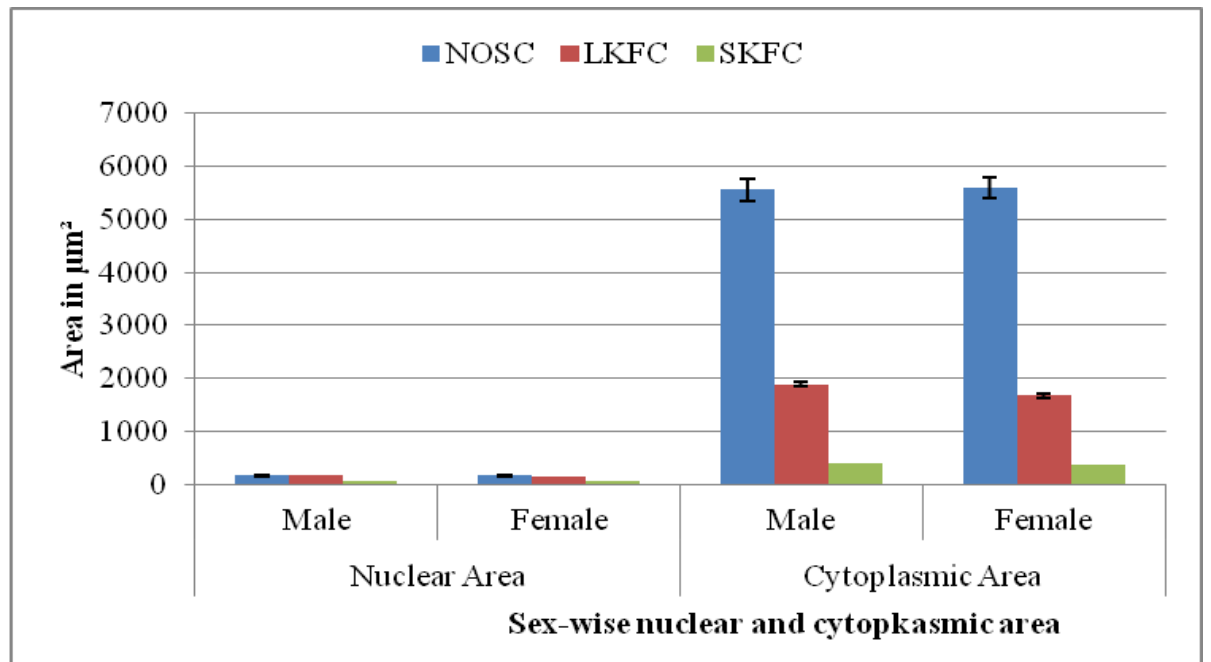

Figure 8 Nuclear and cytoplasmic area of NOSC, LKFC and SKFC in both sexes.

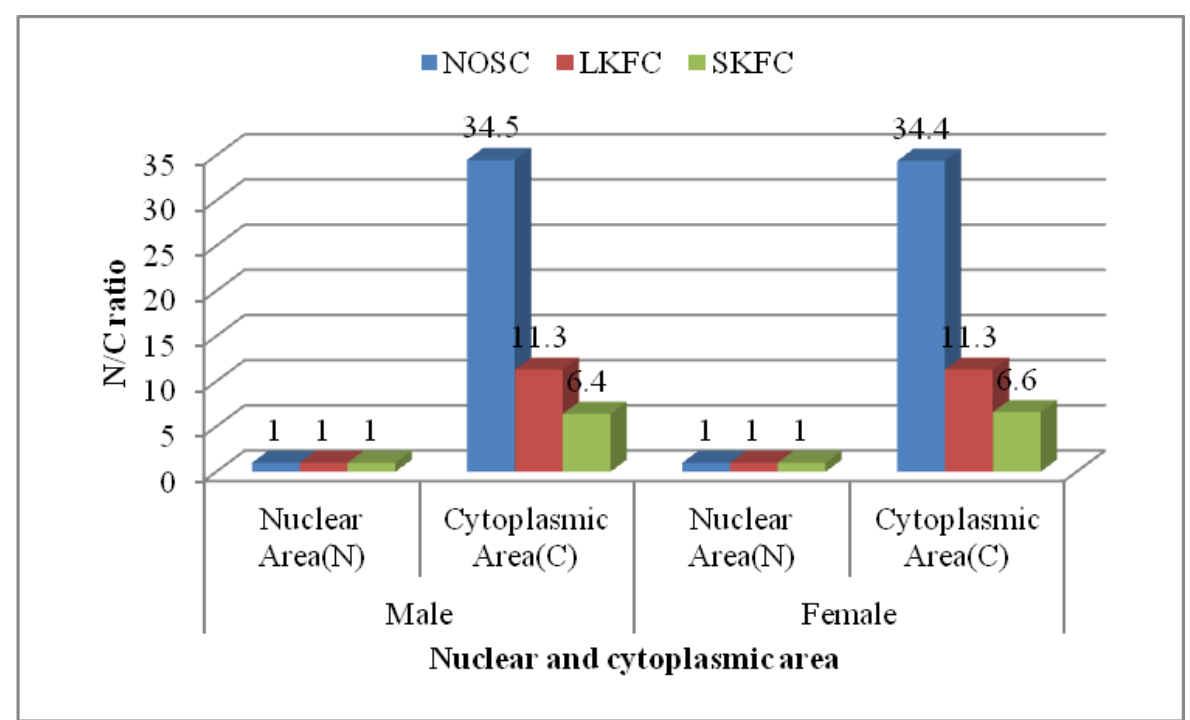

Figure 9 N/C ratios of NOSC, LKFC and SKFC in both sexes. 


\section{Discussion}

Cytological pleomorphism is a unique feature in human oral carcinoma. Occurrences of both LKFCs and SKFCs in varied proportion at different sites of oral cavity indicate that cyto-analysis is a valuable tool in the diagnosis of oral fiber cell carcinoma. However, literatures related to keratinized fiber cells are very few and inadequate. King found fiber cells and tadpole cells only in 2 cases of his series [9]. Parida has reported for the first time that LKFCs and SKFCs are observed in the scraped-smears of oral carcinoma patients [7]. Later on, Mohanta et al. have also reported on the appearance of LKFCs and SKFCs along with other cytological atypias in the exfoliated oral cytosmears from precancerous and cancerous patients [10].

A large number of literatures are devoted to describe the role of collagen fibers, elastic fibers, mast cells etc. in oral submucous fibrosis (OSMF). In view of Rajendran et al., the stroma becomes more and more hyalinized due to progressive deposition and cross-linkage of mature collagen bundles, the tissue suffers resultant ischemia/hypoxia due to physical and biochemical effects of the process. Pursuing further the pathological mechanism, the tissue tries to cope up with hypoxia by actively promoting neo-vascularization as an adaptive response on the part of the mucosa in survival of the atrophic epithelium in OSMF [11].

Ma et al.have suggested that upregulation of the copper-dependent extracellular enzyme lysyl oxidase by fibroblasts in OSMF is important, leading to excessive cross-linking and accumulation of collagen [12]. Trivedy has suggested that substantial amounts of copper released from areca products induces lysyl oxidase activity upregulating collagen synthesis by fibroblasts, facilitating its cross linking and, thereby, inhibiting its degradation [13]. Tilakratne et al. have hypothesized that dense fibrosis and less vascularity of the corium, in the presence of an altered cytokine activity creates a unique environment for carcinogens from both tobacco and areca nut to act on the epithelium. They assumed that carcinogens from areca nut accumulate over a long period of time either on or immediately below the epithelium allowing the carcinogens to act for a longer duration before it diffuses into deeper tissue. According to them less vascularity may deny the quick absorption of carcinogens into the systemic circulation [14]. Viswanathan et al. have reported that collagen, the most abundant protein in the body is responsible for maintaining the functional integrity of tissues including the odontogenic apparatus and was thought that it might also play a role in pathogenesis and expansion of odontogenic cyst [15]. Bhatt and Dholakia studied on the role of mast cells in OSMF and were found to be high in the early stages where the reaction of the tissue to the irritant is strong [16]. In another study, Chavan and. Deshmukh have reported that as the disease advances tissue becomes less reactive, gets hyalinized and occasionally shows degeneration where the mast cells are reduced and are often even fewer than in the normal mucosa [17].

Similarly, oral fibrous hyperplasia (OFH) is thought to result from hyperplasia of collagen fibers. However, details regarding the presence of elastic fibers and reticular fibers other than collagen fibers in OFH are unclear. Oshima has reported that elastic fibers were observed in $57.5 \%$ of OFH cases. The distribution of these fibers was site-specific, and differed from the collagen fibers that constituted OFH. CD34 positivity was observed in the spindle cells constituting OFH accompanied by elastic fibers, and undifferentiated mesenchymal cells around myogenic blood vessels near the lesion were related to the formation of a part of elastic fibers that constituted OFH. It has also been reported that CD34-positive spindle cells participate in the formation of elastofibroma [18]. CD34 is a $110 \mathrm{kDa}$ single-chain trans-membrane glycoprotein and is expressed on immature haematopoietic stem/ progenitor cells, capillary endothelial cells, and embryonic fibroblasts). Consequently, it has been suggested that undifferentiated mesenchymal cells around myogenic blood vessels are related to the formation of the elastic fibers that constitute OFH [19].

Interestingly, none of these fibers, but the KFCs are epidermoid in origin and are reported to be the pleomorphic form of normal oral squamous cells. Not only OSMF but also OFH are some of the premalignant conditions in which mesenchymal-originated fibers are involved. However, genesis of pleomorphic KFCs from oral epithelia may be regarded as oral neo-fibrosis. These cells generally appear to be elongated, lose their elasticity, become stiff and deviate from their normal function due to genetic alteration followed by keratinization [10]. Along with the other fibers, these cells also actively take part in further progression of oral carcinogenesis.

Endo et al. are of opinion that oral exfoliative cytology (EC) technique is useful for preliminary diagnosis of many oral mucosal diseases but it is not a substitute for the routinely-used biopsy to obtain a definitive and non-diagnostic cytological finding. EC is not appropriate as a diagnostic tool for patients with clinical symptoms of desquamative gingivitis. It adds to the cost and delays the definite diagnosis [20].

Patel et al. opined that although oral cytology has disadvantages, a quantitative technique increases the diagnostic ability of exfoliative cytology. It is precise, objective and reproducible.Quantitative methods include both DNA cytophotometry and cytomorphometry. Their cytomorphological values displayed significant variation, elevation in mean nuclear/cytoplasmic ratio $(\mathrm{N} / \mathrm{C})$, significant elevation in mean nuclear area (NA) and cytoplasmic area (CA). The value of the nuclear-cytoplasmic ratio increases with the increase of age [21]. Really, the development of automatic-cytomorphometric methods, DNA content determination, tumor marker 
detection, and diverse molecular level analyses, have aroused interest in exfoliative cytology [22]. That's why, the optimistic workers like Kazanowska et al. are of very much hopeful and expressed their views that 'because of the continuing development of cytological techniques and improvements in cell collecting instruments and methods, there is now a big challenge for oral cytology to become a routine procedure in patients with oral mucosa problems. Oral cytology analysis may, in the near future, be a very useful examination for patients in terms of diagnostics and monitoring, not only during the treatment but also afterwards' [23].

Hande et al. carried out buccal mucosa cytomorphometric analysis of tobacco chewers and concluded that cytomorphometric changes could be the earliest indicators of cellular alterations. They showed a progressive decrease in CA, increase in NA and increase in the ratio of nuclear diameter to cellular diameter (NA: CA) in smears taken from all tobacco users. The decrease of cellular diameter and increase of nuclear size are significant morphologic changes characteristic of actively proliferating cells [24]. Einstein and Sivapathasundharam, in their study reported cytomorphologic alterations in the form of reduction in cellular diameter and increase in nuclear diameter in buccal squames of tobacco users in the South Indian population [25]. This indicates that there could be a relationship between tobacco usage and quantitative alterations of cells.

Cowpe et al. found a significant difference in NA, CA, and NA: CA ratio in males as well as in females. In both major groups (males and females), the difference in NA: CA was significant irrespective of age and sex. Cellular diameter was highest in normal mucosa, lower in dysplastic lesions and lowest in oral squamous cell carcinoma [26].

Ogden $e t$ al. suggested that quantitative techniques, based on the evaluation of parameters such as NA, CA, and NA/CA ratio, may increase the sensitivity of exfoliative cytology for early diagnosis of oral cancers, since these techniques are precise, objective and reproducible [27]. According to Frost, in actively proliferating cells, there is a decrease in the cellular diameter and increase in the nuclear size [28]. Ramaesh et al. found that cellular diameter was highest in normal mucosa, lower in dysplastic lesions and lowest in oral squamous cell carcinoma and nuclear diameter was lowest in normal mucosa, higher in dysplastic lesions, and highest in oral squamous cell carcinoma [29]. During cytomorphometric analysis, Joshi et al. have also reported that the cellular area and cellular diameter was highest in normal mucosa, lower in premalignant lesions and lowest in OSCC lesions [30].

In the present study, the genesis of KFCs may be attributed to the age, sex and addiction to tobacco and alcohol. It has been observed that more number of KFCs was scored from the samples collected from the patients who were also used to keep tobacco in the form of oral snuff, khaini, etc. under the base of the tongue or at the inner sides of buccal mucosa and chewing of betel, betel quid, paan masala and various forms of gutkha for a longer time. Also, more number of KFCs was observed in malignant cases in the age group of 50-69 years than the other two, but the least in 70-89 years of age group in both sexes. In this differential diagnosis, prevalence of LKFCs is more than the SKFCs in lower age group and vice versa, in both sexes. It is important to mention that bundles of LKFCs were detected from only two males and one female who were habituated with chewing of tobacco and drinking of alcohol. However, very few KFCs were detected from the non-addicted individuals. This indicates that there could be a close relationship between addiction to tobacco and alcohol, period of consumption and quantitative alterations of cells. Thus, genotoxicity of tobacco and alcohol play a vital role in transforming normal oral squamous cells into KFCs-may be called as oral neo-fibrosis.

All the above studies suggested that reduced cell size and increased nuclear size are useful early indicators of malignant transformation, and thus exfoliative cytology is of value for monitoring clinically suspect lesions and for early detection of malignancy. In an earlier study, Mohanta et al. have reported that the KFCs were observed to be moderately differentiated, and keratinized [10]. The pattern of keratinization in these pleomorphic KFCs in Papanicolau's stain indicates their epithelial origin. In the present cytomorphometric study, the cytoplasmic area was found to be in reduced state and the nuclear area was in the increased state in each of the KFCs with respect to the NOSCs. The CA and NA were calculated to be the highest in normal oral squamous cell, lower in LKFCs and the lowest in SKFCs and thus corroborates with the earlier findings so far as oral cytopathology is concerned. In a nut-shell, almost all the KFCs were moderately differentiated, keratinized, hyperchromatic and with an increased nuclear/ cytoplasmic ratio- which indicate the state of malignancy. Not only that, the carcinoma formed due to such KFCs may be regarded as oral fiber cell carcinoma.

\section{Conclusion}

Cytoanalysis of oral cells is a relatively inexpensive, simple, easily accessible, non-invasive, and riskfree technique that is well accepted by the patients also. During differential diagnosis, keratinized fiber cells in oral neoplasm are observed to be unique in their architectural configuration. Although, their fiber-like appearance may mimic to the various forms of mesenchymal fibers, these are absolutely epithelial in origin. Pattern of keratinization confirm their epidermal origin. Cytometrically, the cytoplasmic area and the nuclear 
area were calculated to be the highest in normal oral squamous cell, lower in LKFCs and the lowest in SKFCs. In a nut-shell, almost all the KFCs were moderately differentiated, keratinized, hyperchromatic and with an increased nuclear/ cytoplasmic ratio- which indicate the state of malignancy. Thus, it has a practical role in early detection of human oral caecinoma. Transformation of NOSCs to the pleomorphic KFCs may be regarded as oral neo-fibrosis and the carcinoma formed due to such KFCs may be called as oral fiber cell carcinoma. However, genesis of KFCs and their role in oral carcinogenesis needs further study.

\section{Acknowledgements}

Authors are thankful to the Head, P.G. Department of Zoology, Utkal University, Vani Vihar, Bhubaneshwar, Odisha, India for providing library and laboratory facilities and to the Director, AHRCC, Cuttack, Odisha for permitting us to collect samples from the oral cancer patients. One of us, A.Mohanta is grateful to the University Grants Commission (UGC), New Delhi for awarding him UGC Meritorious Research Fellowship to carry out the research work.

\section{References}

[1] R.S.K. Bhavnagar, S.K. Goje, V.K. Hazarey, S.M. Ganvir, Cytomorphometric analysis for evaluation of cell diameter, nuclear diameter and micronuclei for detection of oral premalignant and malignant lesions, Journal of Oral Biosciences, 53(2), 2011, 158169 .

[2] S. Silverman, H. Becks, S.M. Farber,The diagnostic value of intra-oral cytology. J Dent Res, 37, $1977,195-205$.

[3] N.G.Stromby, Experience with buccal smears in the general cytopathology laboratory. Cancer, 23, 1999 , 3-6.

[4] H.G. Ahmed, A.M. Idris, S.O. Ibrahim, Study of oral epithelial atypia among Sudanese tobacco users by exfoliative cytology. Anticancer Res, 23, 2003, 1943-9.

[5] A. Singh, Role of exfoliative cytology in oral lesions: with special reference to rule out malignancy, Journal of college of Medical Sciences-Nepal, 6(2), 2010, 29-37.

[6] E.T. Mc Kinley, General cytologic principles. (In B.F. Atkinsons (Ed) Atlas of Diagnostic Cytopathology, $2^{\text {nd }}$ Edition. Saunder, Elsevier Inc., Philadelphia, 2004).

[7] G. Parida, Diagnostic cells in scrape cytology of squamous cell carcinoma, Acta Cytol, 45, 2001, 1085-6.

[8] A. Mohanta, P.K. Mohanty, G. Parida, Keratinized Spindle Cell: A Diagnostic Cytological Atypia in Human Oral Carcinoma, IOSR Journal of Dental and Medical Sciences ,13(8.IV), 2014, 72-80.

[9] O.H. King, The cytology of common and uncommon oral malignancies, Acta Cytol, 6, 1962, 348-54.

[10] A. Mohanta, P.K. Mohanty, G. Parida, Pattern of Keratinization in Oral Squamous Cells during Carcinogenesis, IOSR Journal of Dental and Medical Sciences, 13 ( 7.IV), 2014, 83-9

[11] R. Rajendran, S. Paul, P.P. Mathews, J. Raghul, M. Mohanty, Characterization and quantification of mucosal vasculature in oral submucous fibrosis. Ind J Dent Res, 16, 2005, 83-91.

[12] R.H. Ma, C.C. Tsai, T.Y. Shieh, Increased lysyl oxidase activity in fibroblasts cultured from oral submucous fibrosis associated with betel nut chewing in Taiwan, J Oral Pathol Med, 24, 1995, 407-12.

[13] C. Trivedy, D. Baldwin, S. Warnakulasuriya, N. Johnson, T. Peters, Copper content in Areca catechu (betel nut) products and oral submucous fibrosis, The Lancet, 349, May 17, 1997, 1447.

[14] W.M. Tilakratne, M.F. Klinikowski, T. Saku, T.J. Peters, S.Warnakulasuriya, Oral submucous fibrosis: review on etiology and pathogenesis. Oral Oncol, 42, 2006, 561-8.

[15] S Viswanathan, R Venkatapathy, B Danasekaran, Role of collagen fibres in the expansion of odontogenic cysts - A Histochemical Study. The Internet Journal of Pathology, 11 (2), 2010, 11-18.

[16] A.P. Bhatt, H.M. Dholakia, Mast cell density in oral submucous fibrosis. J Ind Dent Assoc, 49, 1977, $187-191$.

[17] S. Chavan, R.S. Deshmukh, Quantitative analysis of mast cells in oral submucous fibrosis, Al Ameen J Med Sci, 6(2), 2013,144149 .

[18] M. Oshima, Histopathological and immunohistochemical studies of the distribution of elastic fibers in oral fibrous hyperplasia, Int $\mathbf{J}$ Oral-Med Sci, 12(4), 2014, 216-224.

[19] Krause DS, Fackler MJ, Civin CI, May WS. CD34: structure, biology and clinical utility. Blood, 87, 1996, 1-13.

[20] H. Endo, T.D. Rees, K. Kuyama, M. Matsue, H. Yamamoto, Use of oral exfoliative cytology to diagnose desquamative gingivitis: a pilot study. Quintessence Int, 39, 2008, 152-161.

[21] K.Kazanowska, A. Hałon, M. Radwan-Oczko, The role and application of exfoliative cytology in the diagnosis of oral mucosa pathology -Contemporary knowledge with review of the literature, Adv Clin Exp Med, 23(2), 2014, 299-305.

[22] P.V. Patel, S.Kumar, V.Kumar, G.Vidya, Quantitative cytomorphometric analysis of exfoliated normal gingival cells. J Cytol, 28, 2011, 66-72.

[23] G.R. Ogden, The future role for oral exfoliative cytology - bleak or bright? Oral Oncol, 33, $1997,2-4$.

[24] A.H. Hande, M.S. Chaudhary, Cytomorphometric analysis of buccal mucosa of tobacco chewers. Rom J Morphol Embryol, 51, 2010, 527-532.

[25] T.B. Einstein, B. Sivapathasundharam, Cytomorphometric analysis of the buccal mucosa of tobacco users. Indian J Dent Res, 16, 2005, 42-46.

[26] J.G. Cowpe, R.B. Longmore, M.W. Green, Quantitative exfoliative cytology of normal oral squames: an age, site and sex-related survey. J R Soc Med, 78, 1985, 995-1004.

[27] G.R. Ogden, J.G. Cowpe, A.J. Wight, Oral exfoliative cytology: review of methods of assessment. J Oral Pathol Med, 26, 1997, 201-205.

[28] J.K. Frost, Pathologic processes affecting cells from inflammation to cancer (In: Bibbo M, editor. Comprehensive Cytopathology. Second edition, W.B.Saunders Company, Philadelphia, 1997).

[29] T. Ramaesh, B.R. Mendis, N. Ratnatunga, R.O. Thattil, Cytomorphometric analysis of squames obtained from normal oral mucosa and lesions of leukoplakia and squamous cell carcinoma. J Oral Pathol Med, 27, 1998, 83-86.

[30] P.S. Joshi, M.S. Kaijkar, Cytomorphometric analysis of oral premalignant and malignant lesions using feulgen stain and exfoliative brush cytology, J Interdiscipl Histopathol, 1(4), 2013, 204-211. 